Article

\title{
Soil Moisture Variation in a Farmed Dry-Hot Valley Catchment Evaluated by a Redundancy Analysis Approach
}

\author{
Li Rong ${ }^{1,2}$, Xingwu Duan ${ }^{1,2, *}$, Detai Feng ${ }^{2}$ and Guangli Zhang ${ }^{2}$ \\ 1 Yunnan Key Laboratory of International Rivers and Trans-boundary Eco-security, Kunming 650091, China; \\ rongli@ynu.edu.cn \\ 2 Institute of International Rivers and Eco-security, Yunnan University, Kunming 650091, China; \\ feng_detai@126.com (D.F.); sunnyrong@163.com (G.Z.) \\ * Correspondence: xwduan@ynu.edu.cn; Tel.: +86-871-6503-4577 \\ Academic Editor: Timothy R. Green
}

Received: 24 October 2016; Accepted: 3 February 2017; Published: 7 February 2017

\begin{abstract}
Farmed catchments have greater temporal and spatial heterogeneity of soil moisture than natural catchments. Increased knowledge about the variation of soil moisture in farmed catchments has important implications for the adoption of appropriate tillage measures for agriculture. The purpose of this study was to determine the spatial and temporal variability of soil moisture as controlled by the environment on a farmed catchment in a typical dry-hot valley (DHV) by integrating geostatistical and redundancy analysis (RDA). We monitored soil moisture in topsoil $(0-20 \mathrm{~cm})$ and subsoil $(20-40 \mathrm{~cm})$ layers at 51 points on eight occasions from July 2012 to March 2014, and determined the environmental factors of soil particle-size distribution, soil organic matter, slope aspect, slope gradient, elevation, and a topographic wetness index (WI) modified for semiarid conditions at each point. The results showed that, under the influence of high evaporation, soil moisture in the topsoil was significantly lower than that of subsoil in the DHV. In this study, we observed a strong temporal variation of soil moisture, which was influenced by the seasonal variation of crop cover and lagged behind that of rainfall. Relatively high soil moisture levels were found on the watershed divide and hillside sites of the catchment, and lower on the valleyside sites. Different from other studies, RDA analysis indicated that the WI was not correlated with soil moisture in the DHV; instead, clay and sand levels were the dominant control factor of soil moisture in the farmed DHV. We proposed that soil erosion in the DHV could lead to such increases of sand and decreases of clay content, thus influencing soil moisture content. Soil and water conservation measures will be especially important for valleyside sites with steep slopes.
\end{abstract}

Keywords: soil moisture; farmed catchment; redundancy analysis; upper red river

\section{Introduction}

Soil moisture is an important component of the complex and interacting continuum soil-vegetationatmosphere system. It indirectly influences earth surface processes, such as surface runoff, erosion, chemical exchange, as well as transport of solutes and water [1-4]. The interactions between soil moisture, plants, and atmosphere affect vegetation growth and carbon cycling, especially in arid and semi-arid areas where evaporation is greater than the cumulative rainfall [5]. However, soil moisture varies not only in space, but also in time [6], and assessing the temporal and spatial distribution of soil moisture has become one of the major challenges for hydrology and bioclimatology in recent years [7].

The temporal and spatial variability of soil moisture and the relationship between environmental conditions and soil moisture have been widely studied in the past few years [1,4]. We know from these 
studies that the dominant factors influencing soil moisture are vegetation [8-13], topography [7,14-19], and soil properties $[15,16]$. In these studies, correlation analysis was firstly used to calculate the relationships between the soil moisture and environmental variables. Subsequently, multiple regression and principal component analysis were applied to detect the relative importance of the different variables. There is only one response variable in these statistical methods, in which the data of the response variable is usually the mean value for all monitoring occasions. Redundancy analysis (RDA), a technology of canonical ordination, combines regression and principal component analysis (PCA), in which ordination axes are constrained to be linear combinations of environmental variables [20]. RDA summarizes all of the variance of the response variables and provides a synthetic and simple interpretation of the relationships between multiple response and explanatory variables [21]. RDA can characterize the significance of multiple environmental variables as controls for biological processes, and has been widely applied in identification key environmental factors controls on plant [22,23], microorganism [24,25], soil [26,27] and other processes [28]. The advantage of RDA allows direct assessment of the relationship between known environmental variables and variation in the multivariate data. RDA analysis has been most extensively used in the ecological sciences [29]. However, few studies have applied RDA to the analysis of the variations of soil moisture.

Variability in soil moisture among different land uses has received much interest in recent years $[11-13,16]$. Land use and cover can affect topsoil structure, thereby changing the spatial and temporal distribution of soil moisture $[8,13,17,30]$. Compared to catchments with natural or artificial vegetation, farmed catchments exhibit greater temporal and spatial heterogeneity of soil moisture as a result of agricultural practices and land management [17,31,32]. However, only a few studies have focused on the temporal and spatial variability and environmental controls on soil moisture in farmed catchments [17,33]. Hawley et al. [33] showed that topography was the most important factor controlling the distribution of soil moisture in small agricultural catchments in Chickasha, Oklahoma. Hébrard et al. [17] found that soil surface characteristics were the main factors controlling the temporal and spatial distribution of surface soil moisture in both wet and dry periods in a farmed Mediterranean catchment. Clearly, the importance of environmental factors on farmland soil moisture varies with study areas.

The dry-hot valley region in Southwestern China is a typical semi-arid area with annual rainfall significantly below evaporation levels, and includes parts of the deeply incised valleys along the $\mathrm{Nu}$, Lancang, Yuanjiang, Jinsha, and Nanpan river basins [34]. Because of the abundant sunshine and the quantity of heat, the DHV plays a very important role in local crop and fruit production [35]. The majority of the rainfall events are concentrated during the rainy season, which account for $80 \% \sim 90 \%$ of the total annual rainfall in these areas [36]. However, low annual rainfall coupled with high evaporative demand limit crop production [37,38]. Moreover, the slope gradient can reach more than $35^{\circ}$ in the DHV and thus can be described as very steep slopes [39]. The common steep slope cultivation can, without appropriate conservation efforts, result in dramatic deterioration of natural environment, vegetation destruction and serious soil erosion in the DHVs [38-41]. Under these conditions, soil moisture content is regarded as the main limiting factor for plant growth and crop production in this area $[38,42]$. Nevertheless, farmed land cultivation is the main source of food and income for local people, little is known about the spatial and temporal variability and environmental factors controlling the soil moisture for farmed land in the DHV. Increased knowledge about these issues has important implications for the local hydrology of farmed catchments, and is critical in efforts to adopt appropriate tillage measures for local agriculture.

In this study, we focused on the dry hot valley (DHV) region in Southwest China, and selected a farmed catchment with uniform management practices as case-study areas. The purpose of our study was to (1) evaluate temporal and spatial variability of soil moisture at the catchment-scale in agricultural lands of the DHV; (2) explore the main environmental controls on soil moisture by using redundancy analysis. 


\section{Materials and Methods}

\subsection{Study Area}

The Laozhai agricultural catchment used in this study is located on the right bank of the Yuanjiang River DHV (latitude $23^{\circ} 57^{\prime} 44^{\prime \prime} \mathrm{N}$ to $23^{\circ} 58^{\prime} 7^{\prime \prime} \mathrm{N}$, longitude $101^{\circ} 38^{\prime} 13^{\prime \prime}$ E to $101^{\circ} 39^{\prime} 10^{\prime \prime}$ E) (Figure 1). Southwestern warm and wet monsoons, coming from the Indian Ocean, are blocked by the Ailao Mountains on the right bank of the Yuanjiang River, resulting in a Foehn effect and a dry and hot climate in the Yuanjiang River valley [42]. The local climate is characterized by a high heat flux, high accumulated temperature, hot summers, warm winters, low rainfall, high evaporation, and low humidity. The annual average temperature is $23.9^{\circ} \mathrm{C}$. The annual precipitation is $781 \mathrm{~mm}$ and the annual potential evaporation is $2892 \mathrm{~mm}$, resulting in extreme aridity of this region in the dry season. Eighty percent of the annual precipitation is concentrated in the rainy season (late May to mid-October); the dry season is about 7 months long. The Laozhai catchment covers an area of $0.57 \mathrm{~km}^{2}$, about $95 \%$ of which is farmland. Corn (Zea mays L.) and sugarcane (Saccharum sinense Roxb.) are planted in the rainy season. The Torrid red soil, widely distributed in this area, has a thin soil layer and high sand content [43].
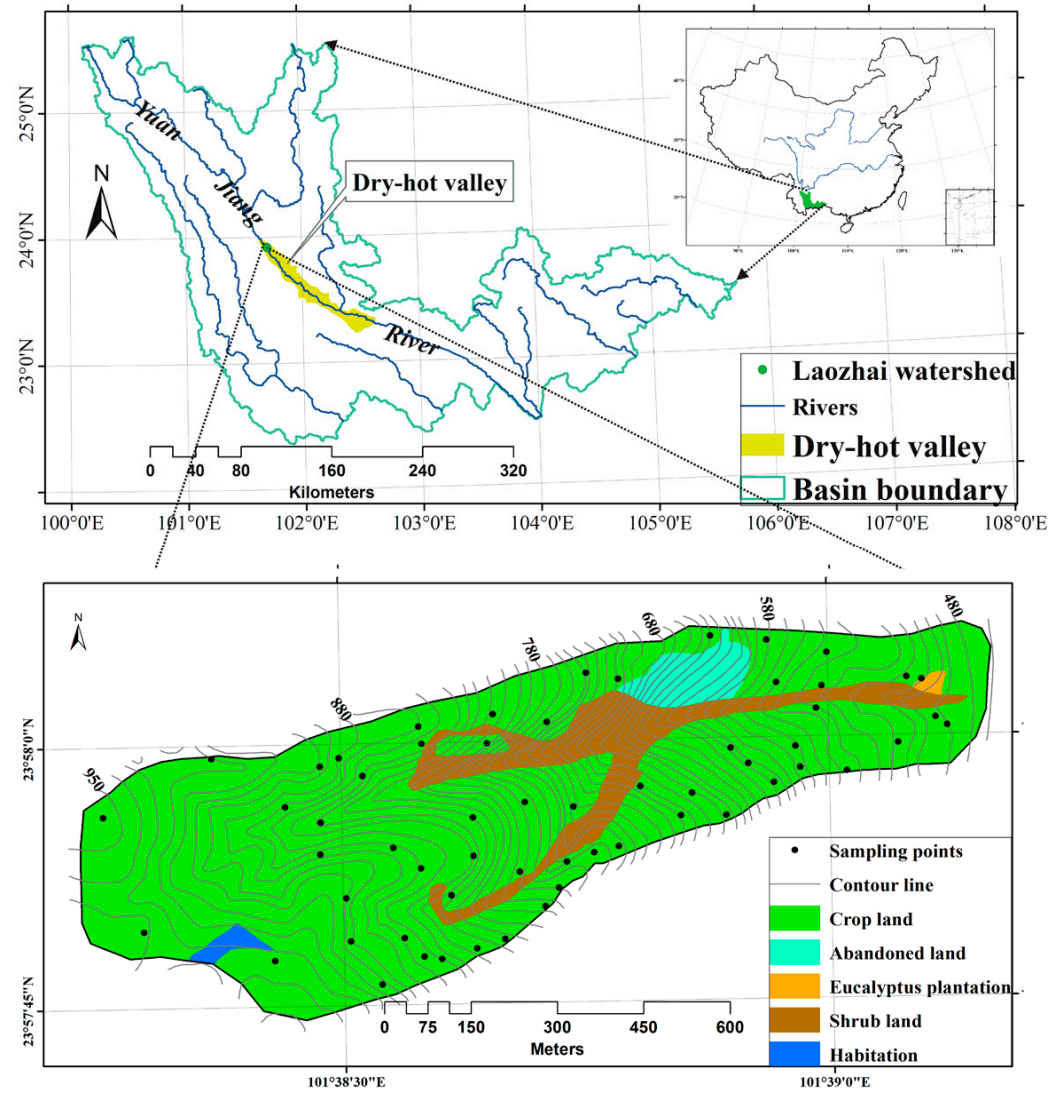

Figure 1. Study area and sampling points at the Laozhai catchment in the DHV, Southwestern China. Contour interval: $10 \mathrm{~m}$. Contour interval is the same for the following figures.

\subsection{Soil Moisture Monitoring}

Fifty-one sampling points were selected for the monitoring of soil moisture at the Laozhai catchment (Figure 1), considering the following factors: (1) uniform crop and agricultural management practices; (2) lack of major human or natural perturbations (canals, roads, gullies or landslides); and (3) presence of all slope positions (valleyside, hillside, watershed divide, and toe slope). At each monitoring point, soil samples of topsoil $(0-20 \mathrm{~cm})$ and subsoil $(20-40 \mathrm{~cm})$ layers were collected using 
a soil auger with a 5-cm diameter on eight occasions from July 2012 to March 2014. After collection, samples were placed in aluminum cans with tight-fitting lids. Soil moisture was determined by the oven-drying method [44]. After being weighed, fresh samples were oven-dried for $24-48 \mathrm{~h}$ at $105{ }^{\circ} \mathrm{C}$ until a constant weight. Gravimetric soil moisture content (in percent) of each sample was calculated as the ratio of the mass of the soil moisture (mass of wet soil minus mass of dry soil) to the mass of the dry soil. Rainfall was recorded using an automatic tipping bucket rain gauge located in the Laozhai catchment. The temporal resolution of rainfall intensity measurements was $60 \mathrm{~s}$.

\subsection{Environmental Variables}

At each monitoring point, additional topsoil and subsoil samples were collected to determine soil particle-size distribution and soil organic matter (SOM) content. Soil samples were air dried at room temperature and sieved through a 2-mm nylon sieve. Particle size distribution was measured using the pipette method after $\mathrm{H}_{2} \mathrm{O}_{2}$ treatment to remove organic matter; the sand fraction was 0.020-2.000 $\mathrm{mm}$ in diameter, silt $0.002-0.020 \mathrm{~mm}$, and clay <0.002 $\mathrm{mm}$ [44]. SOM was measured using a combustion method after soil samples were sieved through a $0.15 \mathrm{~mm}$ mesh [44]. Topographic variables, including elevation, slope gradient, aspect and upslope contributing area $\left(\mathrm{A}_{\mathrm{s}}\right)$ were estimated from a Digital Elevation Model with a resolution of $5 \mathrm{~m}$ based on a 1:10,000 digital topographic map of this catchment by using ArcGIS 10.0 (ESRI, Redland, CA, USA).Topographic wetness index is considered a good indicator of soil moisture pattern at different zones where overland flow dominates water transport processes [16,45]. Considering the dry-hot valley region with high evaporation, we computed topographic wetness index based on the model of Gómez-Plaza et al. [16] for semiarid conditions, which was derived from the index of Beven and Kirby [45]:

$$
\mathrm{WI}=\ln \left(\frac{\text { Aspect } \times \mathrm{A}_{\mathrm{s}}}{\text { slope }}\right)
$$

where WI is the topographic wetness index. Calculation of WI was also completed in the spatial analyst in the ArcGIS 10.0 (ESRI, Redland, CA, USA).

$\mathrm{A}_{\mathrm{S}}$ (units $=\mathrm{m}^{2} / \mathrm{m}$ ) is the upslope contributing area per unit contour length at a point and this unit area has also been called the specific catchment [46].

Aspect was also calculated in the spatial analyst in the ArcGIS 10.0 (ESRI, Redland, CA, USA), which was measured in degrees clockwise from north in the ArcGIS. As the same as Gómez-Plaza et al. [16], we simplified the analysis of the aspect by defining eight classes of slope orientation assigning a number between 1 and 8 to each class according to a range of degrees as shown in Figure 2.

Slope (units $=\mathrm{m} / \mathrm{m}$ ) is the tangent of local slope gradient of the terrain at a point [46]. Slope gradient was assigned to 0.000001 , if slope gradient is $0^{\circ}$ in the spatial analyst in the ArcGIS 10.0 (ESRI, Redland, CA, USA).

For a more detailed explanation of this formula, see Gómez-Plaza et al. [16], Beven and Kirkby [45] and Moore et al. [46].

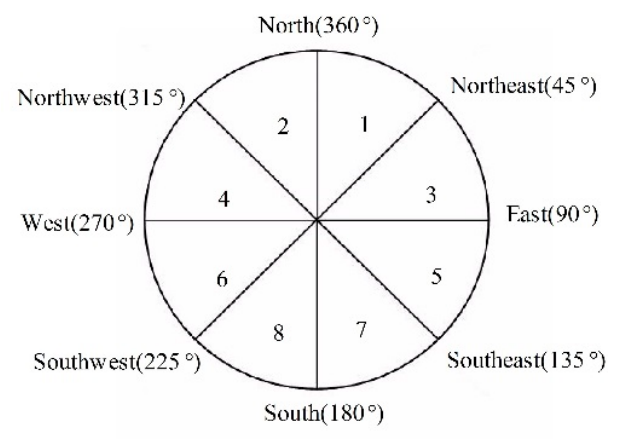

Figure 2. Number assigned to each sampling site according to its aspect. 


\subsection{Statistical Analyses}

One-Sample Kolmogorov-Smirnov (K-S) test was performed to test whether the soil moisture and environmental variable data follow normal distribution. Independent sample $t$ test was used to test the difference between soil moisture in the top- and subsoil layers. Coefficient of variation (CV) was identified as a basic parameter for spatial variability in soil moisture. Possible changes in the soil moisture spatial pattern and controls under different environmental conditions were investigated under wet and dry conditions of soil moisture for eight sampling dates defined using Hierarchical Cluster analysis. If the data of soil moisture and environmental variables are normality, the correlations between them were measured by using Pearson's parametric correlation analysis. If not, Spearman Rank correlation analysis would be used. All above analysis were conducted using SPSS 16.0 for Windows (SPSS Inc., Chicago, IL, USA).

We applied RDA to identify the relative importance of environmental variables in controlling variation in soil moisture and implemented using CANOCO version 5.0 (Microcomputer Power, Ithaca, NY, USA). The choice of this linear ordination method was based on short gradient lengths $(<1.5 \mathrm{SD})$ determined from preliminary detrended correspondence analysis (DCA). The environmental variables used in the analysis were soil particle-size distribution (silt, clay, and sand content), SOM, topographic variables (aspect, elevation, and slope gradient), and topographic wetness index (WI). The relationships between soil moisture content, environmental variables, and sample points were interpreted using a correlation triplot with scaling 2. In the RDA triplot, the correlation between soil moisture and an environmental variable can be approximated by a perpendicular projection of soil moisture arrow-tips onto the line overlaying the environmental variable arrow. The further a projection point fall in the direction indicated by the arrow, the higher the correlation, with a projection point near the coordinate origin (zero point), suggesting near zero correlation. If the projection point aligns in the opposite direction, the predicted correlation is negative [29]. RDA with summarized effects of expl. variables was used to extract environmental variables that most strongly explain variation in the soil moisture. The criteria for environmental variables to be included in the RDA concise model were set to $p \leq 0.05$ by using the summarized effects procedure in CANOCO. To select the most significant variables and to avoid the problem of multicollinearity, the process of selection goes on until no more variables significantly explain the residual variation [24]. For a more in-depth explanation of the RDA, see Šmilauer and Lepš [29].

Ordinary kriging interpolation was used to estimate the spatial distribution of soil moisture in the catchment under wet and dry conditions. If soil moisture data were not normally distributed, they were transformed for geostatistical analysis using a Box-Cox transformation [47]. Then, the semi-variogram model was used to indicate the degree of spatial continuity of the soil moisture content. Three parameters, including nugget, sill, and range, were used to describe the semi-variogram. Common semi-variogram models include the Spherical, Exponential, and Gaussian models, which fit the experimental data [48,49]. Based on the index of the prediction error, including the root mean square, the average standard error, the standardized mean, and the standardized root mean square produced by different semi-variogram models, the Gaussian model was the best theoretical model for the soil moisture data. Based on the Gaussian model, the spatial distribution of the soil moisture in the catchment under wet and dry conditions was estimated using ordinary kriging interpolation [50]. For specific details, see Cressie [47]. Ordinary kriging interpolation was implemented using ArcGIS 10.0 (ESRI, Redland, CA, USA).

\section{Results and Discussion}

\subsection{Temporal Variation of Soil Moisture}

The Kolmogorov-Smirnov test showed environmental variable data and average soil moisture content in the top- and subsoil layers were normally distributed $(p>0.05)$, except for aspect (Table 1$)$. Average soil moisture was $14.67 \%$ and $17.16 \%$ in the top- and subsoil layers, respectively. Independent 
sample $t$-test showed that the average soil moisture in the subsoil was significantly higher than that in topsoil ( $t=-4.32, p=0.00$; probability of two-tailed test by independent sample $t$-test). Higher soil water evaporation and vegetation cover transpiration in the top than in subsoil was mainly responsible for this result [36]. A similar observation had also been made in the semi-arid Loess Plateau [6] and in black soils in Northeastern China [51]. The average CV for the temporal distribution of soil moisture in topsoil was 0.29 , slightly higher than the value of 0.25 for subsoil, indicating that soil moisture in topsoil had greater temporal variability than that in subsoil. Choi and Jacobs [52] also found lower variability in soil moisture in deeper layers than in topsoil, while Penna et al. [53] found the opposite. The balance between evaporation and rainfall may cause higher variability in topsoil than in subsoil $[53,54]$. The average CV for the spatial distribution of soil moisture in top- and subsoil was 0.27 and 0.26 , respectively, and was higher than that observed at large scales $\left(178-242 \mathrm{~km}^{2}\right)(\mathrm{CV}=0.21$ on average [2]), field scale in a low-hill region $(\mathrm{CV}=0.09$ on average [1]), and the hillslope scale in a steep alpine terrain ( $\mathrm{CV}=0.20-0.21$ on average [53]). In general, variability of soil moisture in mountainous regions is expected to be higher relative to other landscapes [36]. The Laozhai catchment is a typical mountainous region [55], where highly heterogeneous topography (Table 1), poor water retention capacity of the Torrid red soil, and high evaporation rates could result in high variability in soil moisture. In addition, the more extensive farming and higher rates of soil erosion in the DHV, compared with other regions, also contributed to the high variability in soil moisture.

Table 1. Descriptive statistics and Kolmogorov-Smirnov test for soil properties in each soil layer and topographic factors (aspect, elevation, and slope gradient), WI and average soil moisture in the topsoil and subsoil layer for 51 sampling points.

\begin{tabular}{|c|c|c|c|c|c|c|c|c|c|}
\hline $\mathrm{EF}^{1}$ & $\mathrm{SL}^{2}$ & $\mathbf{M}^{3}$ & Min. ${ }^{4}$ & Max. $^{5}$ & S.D ${ }^{6}$ & C. $V^{7}$ & $K^{8}$ & $\mathrm{~S}^{9}$ & $P^{10}$ \\
\hline \multirow{2}{*}{ Silt (\%) } & Topsoil & 16.15 & 7.39 & 26.44 & 3.74 & 0.23 & 0.18 & 0.18 & 0.97 \\
\hline & Subsoil & 15.54 & 5.32 & 21.66 & 3.46 & 0.22 & 0.34 & -0.48 & 0.98 \\
\hline \multirow{2}{*}{ Clay (\%) } & Topsoil & 34.12 & 18.17 & 63.72 & 9.42 & 0.28 & 2.80 & 1.34 & 0.42 \\
\hline & Subsoil & 37.40 & 6.54 & 67.05 & 10.48 & 0.28 & 1.91 & 0.33 & 0.67 \\
\hline \multirow{2}{*}{ Sand $(\%)$} & Topsoil & 49.73 & 24.56 & 65.89 & 8.59 & 0.17 & 1.92 & -0.85 & 0.44 \\
\hline & Subsoil & 47.06 & 24.56 & 88.14 & 10.70 & 0.23 & 3.62 & 0.98 & 0.50 \\
\hline \multirow{2}{*}{$\mathrm{SOM}\left(\mathrm{g} \cdot \mathrm{kg}^{-1}\right)$} & Topsoil & 23.37 & 12.28 & 41.63 & 6.06 & 0.26 & 1.33 & 0.80 & 0.29 \\
\hline & Subsoil & 18.18 & 7.41 & 34.95 & 6.05 & 0.33 & 0.27 & 0.80 & 0.12 \\
\hline Aspect & - & 3.29 & 1 & 7 & 2.10 & 0.64 & -1.00 & 0.46 & 0.03 \\
\hline Elevation (m) & - & 740.29 & 490.34 & 940.00 & 144.99 & 0.20 & -1.33 & -0.45 & 0.19 \\
\hline Slope gradient $\left({ }^{\circ}\right)$ & - & 24.99 & 0.00 & 50.44 & 11.54 & 0.46 & 0.47 & -0.16 & 0.85 \\
\hline WI & - & 15.83 & 11.98 & 18.89 & 1.61 & 0.10 & -0.25 & -0.57 & 0.34 \\
\hline \multirow{2}{*}{ Soil moisture (\%) } & Topsoil & 14.67 & 8.99 & 23.35 & 2.59 & 0.18 & 1.92 & 0.77 & 0.31 \\
\hline & Subsoil & 17.16 & 10.00 & 25.66 & 3.19 & 0.19 & 0.33 & -0.00 & 0.95 \\
\hline
\end{tabular}

Notes: ${ }^{1}$ Environmental factors, ${ }^{2}$ Soil layer, ${ }^{3}$ Mean, ${ }^{4}$ Minimum, ${ }^{5}$ Maximum, ${ }^{6}$ Standard deviation, ${ }^{7}$ Coefficient of variations, ${ }^{8}$ Kurtosis, ${ }^{9}$ Skewness, ${ }^{10}$ Probability of two-tailed test by the Kolmogorov-Smirnov test. If the probability is more than 0.05 (the significance at 0.05 level), the data distribution is normal. If not, it is non-standard.

Temporal variation in soil moisture in the two soil layers exhibited a similar pattern during the monitoring period (Figure 3). In 2012, the highest soil moisture was observed in October, but the highest precipitation occurred in August. Although the peak of precipitation in 2013 was observed in August, soil moisture increased gradually from April to September. Temporal variation in soil moisture in the two soil layers lagged behind peak monthly precipitation (Figure 3). This was because crop cover was relatively low, while evaporation increased [52] from March to August 2013; high evaporation can reduce soil moisture despite gradually increasing precipitation. After August, crops such as corn and sugar cane were fully developed, so that the high surface-cover of crops can reduce evaporation [56,57]; as a result, soil moisture exhibited an increasing trend when precipitation decreased. This was different from the temporal variation in soil moisture in natural catchments, where soil moisture changed seasonally strongly corresponding to rainfall amounts $[6,12,19,58]$. 


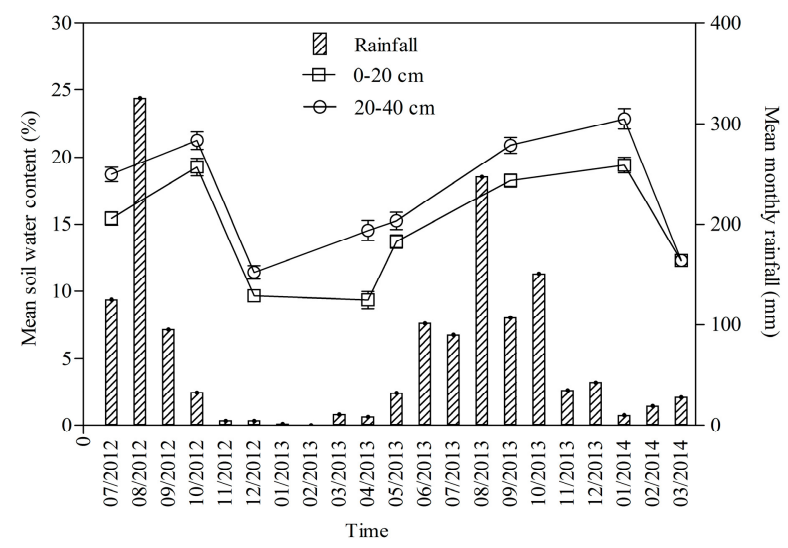

Figure 3. Variations in average soil moisture in the top- and subsoil layers, and monthly rainfall in the Laozhai catchment from July 2012 to March 2014. The bars represent standard error of the mean of 51 samples.

\subsection{Spatial Distribution of Soil Moisture}

It has been shown that the spatial distribution of soil moisture and environmental control factors were strongly affected by the condition of soil moisture $[54,59,60]$. In our study, we identified wet and dry soil moisture conditions by Hierarchical Cluster analysis (Figure 4). Soil moisture conditions of topsoil on sampling dates of 6 October 2012, 16 September 2013, 8 January 2014, and of subsoil on 1 July 2012 was defined as wet. Soil moisture conditions on the remaining sampling dates were defined as dry. Wet conditions referred to spatially average soil moisture content above $18 \%$ in the topsoil and subsoil layers, and dry conditions referred to less than $14 \%$.

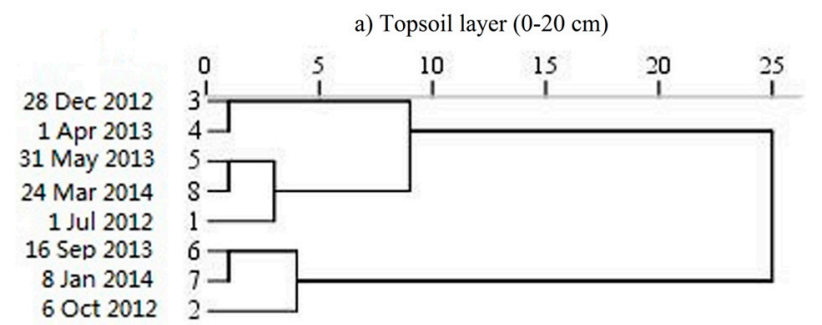

b) Subsoil layer $(20-40 \mathrm{~cm})$

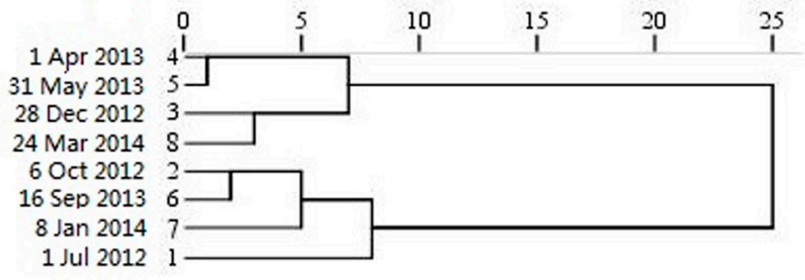

Figure 4. Dendrogram of soil moisture in the top- and subsoil layers using Between-groups linkage.

The data of average soil moisture under wet and dry conditions showed a normal distribution based on the Kolmogorov-Smirnov test (Table 2). Spatial distribution of soil moisture in both soil layers under dry and wet conditions were shown in Figure 5. Soil moisture in both soil layers exhibited a patchy pattern under wet condition, and was relatively evenly distributed under dry conditions. A similar observation was reported from a desertified riparian area in Southern China by Li et al. [61]. Generally, relatively high soil moisture levels were found on the watershed divide and hillside sites of the catchment (Figure 5), and relatively low soil moisture levels were observed on the valleyside sites (Figure 5). Low relief promotes infiltration by surface runoff $[62,63]$; therefore the relatively 
low slope gradient in the watershed divide and hillside sites of the catchment in this study may be responsible for the high soil moisture content. In general, in wet conditions, spatial distribution of soil moisture was dominated by lateral water movement by both surface and subsurface pathways, and steep slopes of the catchment may lead to fast surface runoff from high areas to toe slope [64]. Moreover, a relatively high elevation in the watershed divide region of the catchment may exhibit lower evaporation rates than elsewhere, and promote moisture retention in soil [65] regardless of the soil moisture conditions. Contrary to that, Li et al. [61] found in a semi-arid plateau sites lower soil moisture at higher elevations, and higher soil moisture at lower elevations. Undoubtedly, there was a very variable orographic rain events in the $\mathrm{DHV}$, due to the Foehn phenmena are frequent, resulted in the obvious spatial variability for precipitation. However, we did not analyze the effect of precipitation to the spatial distribution of soil moiusutre because of the limted observation condition, which would be conducted in the further research.

Table 2. Descriptive statistics and Kolmogorov-Smirnov test for average soil moisture for wet and dry conditions.

\begin{tabular}{cccccccccc}
\hline SC $^{\mathbf{1}}$ & SL $^{\mathbf{2}}$ & $\mathbf{M}^{\mathbf{3}}$ & Min. $^{\mathbf{4}}$ & Max. $^{\mathbf{5}}$ & S.D $^{\mathbf{6}}$ & $\mathbf{C . V}^{\mathbf{7}}$ & $\mathbf{K}^{\mathbf{8}}$ & $\mathbf{S ~}^{\mathbf{9}}$ & $\mathbf{P}^{\mathbf{1 0}}$ \\
\hline \multirow{2}{*}{ Wet } & Topsoil & 18.97 & 10.78 & 26.09 & 3.35 & 0.18 & -0.02 & 0.01 & 0.46 \\
& subsoil & 20.93 & 13.18 & 29.74 & 3.62 & 0.17 & 0.25 & 0.03 & 0.67 \\
\hline \multirow{2}{*}{ dry } & Topsoil & 12.09 & 6.73 & 23.12 & 2.68 & 0.22 & 4.98 & 1.64 & 0.09 \\
& subsoil & 13.38 & 6.24 & 21.59 & 3.18 & 0.24 & 0.36 & 0.28 & 0.64 \\
\hline
\end{tabular}

Notes: ${ }^{1}$ Soil condition, ${ }^{2}$ Soil layer, ${ }^{3}$ Mean, ${ }^{4}$ Minimum, ${ }^{5}$ Maximum, ${ }^{6}$ Standard deviation, ${ }^{7}$ Coefficient of variations,

${ }^{8}$ Kurtosis, ${ }^{9}$ Skewness, ${ }^{10}$ Probability of two-tailed test by the Kolmogorov-Smirnov test. If the probability is more than 0.05 (the significance at 0.05 level), the data distribution is normal. If not, it is no-standard.

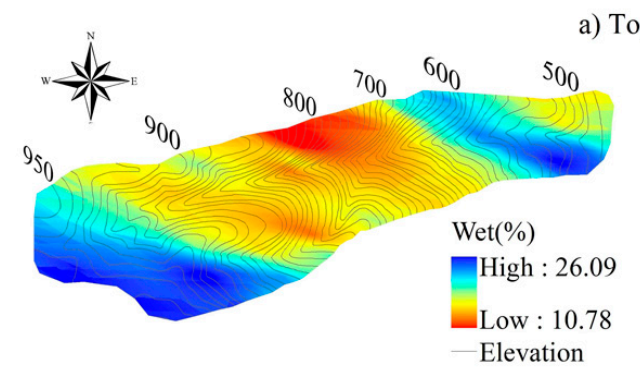

a) Topsoil layer $(0-20 \mathrm{~cm})$

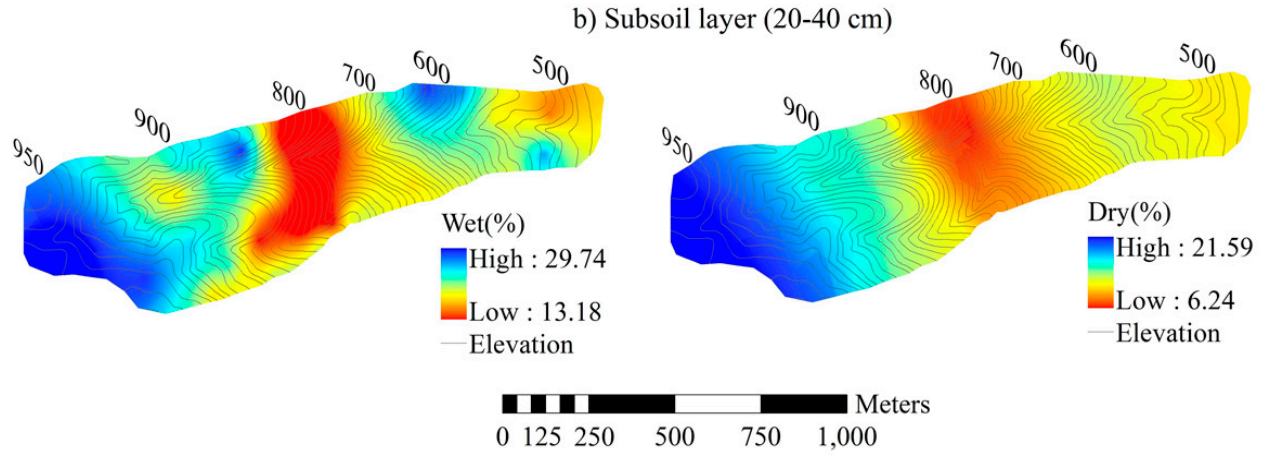

Figure 5. Spatial distributions of soil moisture in the top- and subsoil layers in Laozhai catchment.

\subsection{Correlations between Soil Moisture and Environmental Variables}

Soil moisture in top- and subsoil was significantly positively correlated with clay content, and negatively correlated with sand content in both wet and dry soil moisture conditions (Table 3). Soil particle size distribution had been shown to have a strong influence over soil moisture worldwide [15-17,33]. The significant positive correlation between clay and soil water levels may be due to the fact that the water holding capacity of soil increases with a decrease in the size of soil 
particles [66]. The negative correlation between sand and soil moisture levels may be due to the high infiltration capacity of sand, which favors vertical fluxes of water [16].

Under wet conditions, aspect was not correlated with soil moisture, but slope gradient was negatively correlated with soil moisture in subsoil. Under dry conditions, soil moisture in top- and subsoil exhibited a negative correlation with slope gradient and a positive correlation with elevation, respectively. In general, the steep slope gradient favors runoff flow but should not favor high soil moisture content $[15,16,18,19]$. Thus, the negative correlation was found between soil moisture and slope gradient. Usually, the soil moisture at the point of low elevation would be supplemented by the surface runoff and subsurface flow at the point of high elevation as the runoff is generated at some point [54], consequently resulting in a negative correlation between soil moisture and elevation. In this farmed catchment, soil moisture in topsoil under wet conditions was affected by leaf area index of the crop because of high crop cover, which can decrease the likelihood that a rainfall event results in a topographic redistribution of soil water [67]. Under dry conditions, when land was fallow after harvesting, the topographic factor became important in determining soil moisture content. However, a residual cover crop remained after harvesting, and any type of conservation tillage may also affect soil moisture [68-71].

Weak correlations between soil moisture and WI were observed under wet and dry conditions in both soil layers (Table 3). Since the development of a composite WI [3], a strong relationship between WI and soil moisture content had been shown worldwide. Gómez-Plaza et al. [16] demonstrated that WI could explain $29 \%, 44 \%$, and $32 \%$ of soil moisture variability in wet, medium, and dry conditions, respectively, in a semiarid catchment of Southwestern Spain. Takagi and Lin [72] found that WI explained $28.5 \%$ and $40.1 \%$ of soil moisture variability at 10 and $40 \mathrm{~cm}$ depth, respectively, in shale-hill catchments in a humid temperate region of the U.S. However, most of these studies focused on natural catchments or hillslopes. In our study, the farmed valley catchment was largely influenced by dry and hot climate and high sand content; thus, the relationship between WI and soil moisture was weak. This implied that the WI, a composite topographic attribute, may not be effective at predicting the spatial variation of soil moisture in farmed catchments of the DHV.

Table 3. Correlation coefficients between soil moisture content and environmental variables in topand subsoil layer.

\begin{tabular}{ccccccccc}
\hline \multirow{2}{*}{ Environmental Factors } & \multicolumn{4}{c}{ Topsoil } & \multicolumn{4}{c}{ Subsoil } \\
\cline { 2 - 9 } & \multicolumn{2}{c}{ Wet Condition } & \multicolumn{2}{c}{ Dry Condition } & Wet Condition & \multicolumn{2}{c}{ Dry Condition } \\
\cline { 2 - 9 } & $\mathbf{R}^{\mathbf{1}}$ & $\mathbf{P}^{\mathbf{2}}$ & $\mathbf{R}^{\mathbf{1}}$ & $\mathbf{P}^{\mathbf{2}}$ & $\mathbf{R}^{\mathbf{1}}$ & $\mathbf{P}^{\mathbf{2}}$ & $\mathbf{R}^{\mathbf{1}}$ & $\mathbf{P}^{\mathbf{2}}$ \\
\hline Silt & 0.26 & 0.06 & -0.09 & 0.52 & 0.12 & 0.39 & -0.12 & 0.39 \\
Clay & $0.44^{* *}$ & 0.00 & $0.74^{* *}$ & 0.00 & $0.47^{* *}$ & 0.00 & $0.59^{* *}$ & 0.00 \\
Sand & $-0.60^{* *}$ & 0.00 & $-0.78^{* *}$ & 0.00 & $-0.50^{* *}$ & 0.00 & $-0.54^{* *}$ & 0.00 \\
SOM & 0.22 & 0.12 & 0.18 & 0.20 & -0.09 & 0.52 & -0.04 & 0.76 \\
Aspect & -0.20 & 0.15 & -0.02 & 0.91 & -0.07 & 0.63 & -0.02 & 0.88 \\
Elevation & -0.06 & 0.69 & 0.26 & 0.07 & 0.08 & 0.56 & $0.33^{*}$ & 0.02 \\
Slope gradient & -0.26 & 0.06 & $-0.35^{*}$ & 0.01 & $-0.31^{*}$ & 0.03 & -0.23 & 0.10 \\
WI & 0.08 & 0.60 & 0.22 & 0.11 & 0.18 & 0.21 & 0.19 & 0.17 \\
\hline
\end{tabular}

Notes: ${ }^{1}$ correlation coefficient, ${ }^{2}$ Probability of two-tailed test, ${ }^{*}$ and ${ }^{* *}$ indicate that the correlation is statistically significant at the 0.05 and 0.01 levels, respectively.

\subsection{The Dominant Controls on Soil Moisture}

RDA analysis of environmental factors and soil moisture was displayed on a triplot with samples included (Figure 6). Eight environmental variables accounted for $38.3 \%$ and $47.7 \%$ of the total variation in topsoil moisture under wet and dry conditions, respectively, and for $26.1 \%$ and $34.9 \%$ in subsoil (Table 4). The cumulative variance obtained by the first two canonical axes contributed more than $23 \%$ to the total variance in the two soil layers under wet and dry conditions (Table 4). The first ordination axis was strongly correlated with sand and clay content, and the second with elevation, indicating that 
the first axis of the RDA mainly represented soil properties of sand and clay, and the second axis those of topographic environmental factors (Table 5, Figure 6).

The results of the RDA differed somewhat from the correlation analysis described above, but not fundamentally. The RDA confirmed the relationships among particle-size distribution, slope gradient, and soil moisture in the correlation analysis. However, elevation was not only correlated with soil moisture in the subsoil layer but also for the topsoil layer under dry conditions in the RDA, yet aspect showed no significant correlation to soil moisture in the subsoil under wet conditions (Table 6, Figure 6). The results of conditional effects showed that only two environmental variables were contained in the RDA concise model in topsoil: sand and clay for wet conditions, and sand and elevation for dry conditions, and only one environmental variable was contained in the subsoil: sand for wet conditions, and clay for dry conditions (Table 6). These analyses showed that the spatial distribution of soil moisture in topsoil and subsoil was primarily controlled by the particle-size distribution of sand and clay in both soil moisture conditions (Table 6).
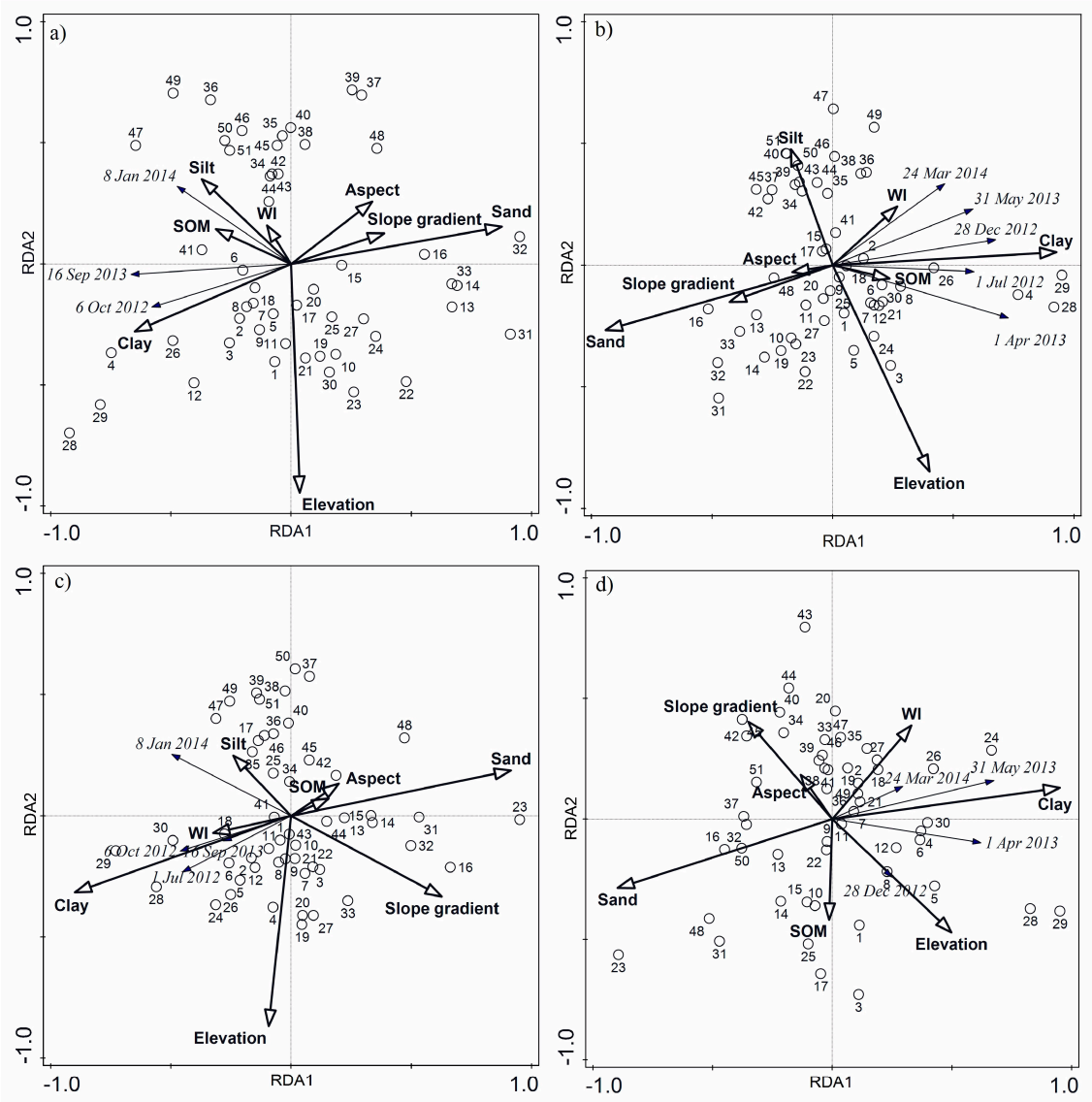

Figure 6. RDA triplot of the soil moisture content data constrained by all environmental variables, scaling 2 (triplot interpretation rules: (1) Projecting an object at right angles on a response or a quantitative explanatory variable approximates the value of the object along that variable; (2) The angles in the triplot between the response and explanatory variables, and between the response variables themselves or the explanatory variables themselves, reflect their correlations). Soil moisture and environmental variables are represented by arrows (thin for soil moisture, thick for environmental variables); samples are shown as circles. The bottom and left-hand axes are for the objects and response variables, the top and right-hand axes are for the explanatory variables. (a) wet condition of soil moisture in topsoil layer; (b) dry condition of soil moisture in topsoil layer; (c) wet condition of soil moisture in subsoil layer; (d) dry condition of soil moisture in subsoil layer. 
Table 4. Characteristics of the first four axes from the RDA analysis.

\begin{tabular}{ccccccccc}
\hline \multirow{2}{*}{ SL $^{\mathbf{1}}$} & \multicolumn{4}{c}{ Wet Condition } & \multicolumn{4}{c}{ Dry Condition } \\
\cline { 2 - 9 } & Statistic & $\mathbf{E}^{\mathbf{2}}$ & $\mathbf{E V}^{\mathbf{3}} \mathbf{( \% )}$ & $\mathbf{E F V}^{\mathbf{4}} \mathbf{( \% )}$ & Statistic & $\mathbf{E}^{\mathbf{2}}$ & $\mathbf{E V}^{\mathbf{3}} \mathbf{( \% )}$ & $\mathbf{E F V}^{\mathbf{4}} \mathbf{( \% )}$ \\
\hline \multirow{3}{*}{ Topsoil } & Axis 1 & 0.32 & 32.23 & 84.13 & Axis 1 & 0.40 & 40.37 & 84.67 \\
& Axis 2 & 0.05 & 37.12 & 96.90 & Axis 2 & 0.04 & 44.73 & 93.81 \\
& Axis 3 & 0.01 & 38.30 & 100.00 & Axis 3 & 0.02 & 46.49 & 97.50 \\
& Axis 4 & - & - & - & Axis 4 & 0.01 & 47.41 & 99.43 \\
\hline \multirow{3}{*}{ Subsoil } & Axis 1 & 0.19 & 19.33 & 74.05 & Axis 1 & 0.31 & 30.96 & 88.66 \\
& Axis 2 & 0.04 & 23.26 & 89.11 & Axis 2 & 0.02 & 33.45 & 95.79 \\
& Axis 3 & 0.02 & 25.45 & 97.52 & Axis 3 & 0.01 & 34.66 & 99.25 \\
& Axis 4 & 0.01 & 26.10 & 100.00 & Axis 4 & 0.00 & 34.92 & 100.00 \\
\hline
\end{tabular}

Notes: ${ }^{1}$ Soil layer, ${ }^{2}$ Eigenvalues, ${ }^{3}$ Explained variation (cumulative), ${ }^{4}$ Explained fitted variation (cumulative).

Table 5. Correlations between the explanatory variables and the ordination axes in the topsoil and subsoil layer.

\begin{tabular}{|c|c|c|c|c|c|c|c|c|c|}
\hline \multirow{2}{*}{$\mathrm{SL}^{1}$} & \multirow{2}{*}{$\mathrm{V}^{2}$} & \multicolumn{4}{|c|}{ Wet Condition (Correlation Coefficient) } & \multicolumn{4}{|c|}{ Dry Condition (Correlation Coefficient) } \\
\hline & & Axis1 & Axis2 & Axis3 & Axis4 & Axis1 & Axis2 & Axis3 & Axis4 \\
\hline \multirow{8}{*}{ Top $^{3}$} & Silt & 0.26 & 0.18 & 0.21 & 0.00 & -0.14 & 0.32 & 0.21 & -0.17 \\
\hline & Clay & 0.45 & -0.14 & -0.13 & -0.00 & 0.75 & 0.03 & 0.08 & 0.08 \\
\hline & Sand & -0.61 & 0.08 & 0.05 & 0.00 & -0.76 & -0.18 & -0.00 & -0.01 \\
\hline & SOM & 0.22 & 0.07 & -0.03 & 0.00 & 0.19 & -0.04 & 0.02 & 0.08 \\
\hline & Aspect & -0.23 & 0.13 & 0.13 & 0.00 & -0.14 & -0.02 & -0.31 & 0.05 \\
\hline & $\mathrm{El}^{4}$ & -0.02 & -0.48 & -0.00 & -0.00 & 0.33 & -0.50 & -0.03 & -0.09 \\
\hline & Slope ${ }^{5}$ & -0.27 & 0.06 & 0.05 & 0.00 & -0.35 & -0.10 & 0.16 & -0.06 \\
\hline & WI & 0.07 & 0.08 & -0.03 & 0.00 & 0.22 & 0.08 & 0.06 & -0.05 \\
\hline \multirow{8}{*}{ Sub $^{6}$} & Silt & -0.13 & 0.13 & -0.24 & 0.06 & NA & NA & NA & NA \\
\hline & Clay & -0.47 & -0.14 & 0.07 & -0.03 & 0.63 & 0.06 & 0.01 & -0.03 \\
\hline & Sand & 0.51 & 0.10 & 0.08 & -0.02 & -0.60 & -0.14 & 0.07 & 0.04 \\
\hline & SOM & 0.09 & 0.04 & -0.30 & -0.10 & -0.01 & -0.21 & -0.25 & -0.01 \\
\hline & Aspect & 0.11 & 0.07 & 0.04 & -0.09 & -0.09 & -0.09 & -0.04 & 0.12 \\
\hline & $\mathrm{El}^{4}$ & -0.05 & -0.48 & 0.07 & -0.09 & 0.33 & -0.23 & 0.07 & 0.06 \\
\hline & Slope ${ }^{5}$ & 0.35 & -0.18 & -0.11 & 0.12 & -0.24 & 0.20 & -0.01 & 0.03 \\
\hline & WI & -0.18 & -0.04 & -0.02 & 0.05 & 0.22 & 0.19 & 0.00 & 0.09 \\
\hline
\end{tabular}

Notes: ${ }^{1}$ Soil layer, ${ }^{2}$ Variables, ${ }^{3}$ Topsoil, ${ }^{4}$ Elevation, ${ }^{5}$ Slope gradient, ${ }^{6}$ Subsoil, NA in the table indicate that the correlation is statistically not significant at the 0.05 and 0.01 levels, respectively.

Table 6. Results of summarized effects of explanatory variables.

\begin{tabular}{|c|c|c|c|c|c|c|c|c|c|}
\hline \multirow{2}{*}{$\mathrm{SL}^{1}$} & \multirow{2}{*}{ Effects } & \multicolumn{4}{|c|}{ Wet Condition } & \multicolumn{4}{|c|}{ Dry Condition } \\
\hline & & $\mathrm{ExV}^{2}$ & Explained (\%) & $F^{3}$ & $\mathrm{P}^{4}$ & $\mathrm{ExV}^{2}$ & Explained (\%) & $F^{3}$ & $\mathbf{P}^{4}$ \\
\hline \multirow{4}{*}{ Top ${ }^{5}$} & \multirow{3}{*}{ Simple effects } & Sand & 24.9 & 16.2 & 0.002 & Sand & 36.1 & 27.6 & 0.002 \\
\hline & & - & - & - & - & elevation & 9.6 & 5.2 & 0.01 \\
\hline & & - & - & - & & Slope gradient & 7.7 & 4.1 & 0.01 \\
\hline & Conditional effects & Sand & 24.9 & 16.2 & 0.002 & Sand & 36.1 & 27.6 & 0.002 \\
\hline \multirow{3}{*}{ Sub $^{6}$} & \multirow[t]{2}{*}{ Simple effects } & Clay & 14.4 & 8.2 & 0.004 & Sand & 25.2 & 16.5 & 0.002 \\
\hline & & Slope gradient & 8.3 & 4.4 & 0.008 & Elevation & 8.3 & 4.4 & 0.03 \\
\hline & Conditional effects & Sand & 16.4 & 9.6 & 0.002 & Clay & 28.0 & 19.0 & 0.002 \\
\hline
\end{tabular}

Notes: ${ }^{1}$ Soil layer, ${ }^{2}$ Explanatory variables, ${ }^{3}$ Pseudo $-F=\frac{\mathrm{SS}(\hat{\mathrm{Y}}) / \mathrm{m}}{\mathrm{RSS} /(\mathrm{n}-\mathrm{m}-1)}, \mathrm{m}$ is the degrees of freedom of the model, SS $(\hat{Y})$ is the explained variation, RSS is the residual sum of squares, ${ }^{4}$ Probability of two-tailed test, ${ }^{5}$ Topsoil, ${ }^{6}$ Subsoil.

Our study confirmed the dominant role of soil particle-size distribution in controlling the spatial pattern of soil moisture in both soil layers in wet and dry soil conditions at this catchment. The water 
holding capacity of clay and the high infiltration capacity of sand may result in the particular correlations of clay and sand to soil moisture $[16,66]$. As a result, spatial distribution of soil moisture content in our study was similar to the spatial distribution of particle-size distribution of soil at the catchment scale (Figures 5 and 7). The clay content increased from the valleyside to the watershed divide sites (Figure 7), and the soil moisture increased correspondingly (Figure 5). Increasing clay levels were associated with decreasing hydraulic conductivity, which led to a higher water retention capacity than in soils with low clay content $[15,16]$. This is in line with observations made by Baroni and colleagues [59] in a maize field in a semi-humid region. They reported that a low sand content corresponded to soils with high moisture levels. This was the case in our study (Figures 5 and 7). Consequently, higher soil moisture content mainly occurred on the watershed divide and hillside sites with high clay content, and lower soil moisture levels were present in the valleyside areas with the higher sand content than elsewhere; this was observed in both soil layers (Figures 5 and 7). These observations were confirmed by the analysis of the spatial distribution of soil moisture obtained with the RDA triplot. This indicated the dominant role of soil particle-size distribution in driving soil moisture levels in the DHV. On the other hand, it has been widely shown that soil erosion can change the physicochemical properties of soil by increasing sand and decreasing clay levels [73]. Soil erosion in the DHV is severe and could lead to such increases of sand and decreases of clay levels, thus influencing soil moisture content. Therefore, our results are applicable for soil- and water-conservation planning at local scales. In particular, our results indicate that water conservation measures will be especially important for valleyside sites with steep slopes.

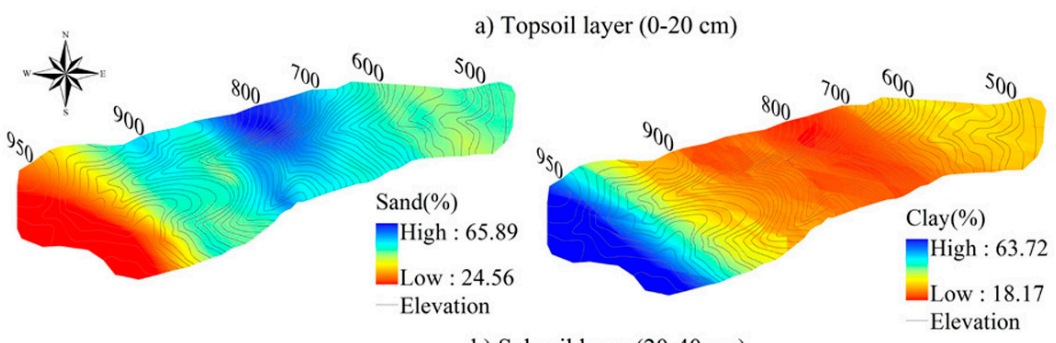

b) Subsoil layer $(20-40 \mathrm{~cm})$

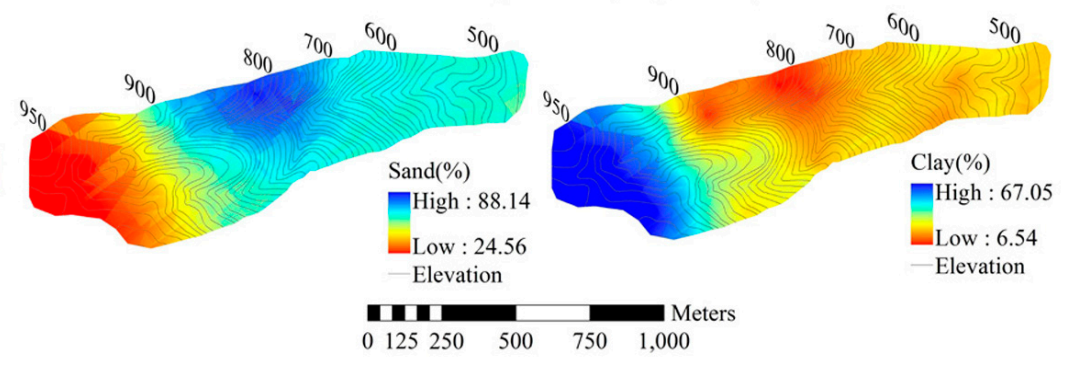

Figure 7. Spatial distributions of soil sand and clay content in the top- and subsoil layers in the Laozhai catchment.

\section{Summary and Conclusions}

We observed a strong temporal variation of soil moisture in the farmed DHV. The study catchment was influenced by the seasonal variation of crop cover, and temporal variation of soil moisture lagged behind that of rainfall. RDA analysis indicated that WI was not correlated with soil moisture in this study location, while soil clay and sand levels were the dominant control factors for soil moisture in the DHV. Geostatistical analysis also confirmed the outcome of the RDA triplot, with high soil moisture content in the summit and shoulder areas of the catchment, exhibiting relatively high clay and low sand levels, and low soil moisture content in the back-slope sites with low clay and high sand levels. This study confirmed the dominant role of soil particle-size distribution in controlling soil moisture regardless of soil moisture conditions in the farmed catchment in the DHV. Soil erosion in the DHV 
is severe and could lead to such increases of sand and decreases of clay levels, thus influencing soil moisture content. Therefore, our results indicate that water conservation measures will be especially important for back-slope sites with steep slopes. Crop variables, such as leaf area index, crop height, crop residue cover as a type of conservation tillage, and water absorption by crop roots, which could also affect soil moisture, are necessary in further studies.

Acknowledgments: We would like to thank Kathryn B. Piatek and Yanbo Li for language editing and for helpful suggestions on the manuscript. This work was funded by the National Natural Science Foundation Project of China (Grant number: 41401614, 41561063, and 41101267), Non-profit Industry Research Project of Chinese Ministry of Water Resources (Grant Number: 201501045), and the Department of Water Resources of Yunnan Province: Water Science and Technology Project (Grant Number: SLKI-2).

Author Contributions: Xingwu Duan conceived and designed the experiments, and revised the paper; Guangli Zhang and Detai Feng performed the experiments; Li Rong analyzed the data, contributed analysis tools, and wrote the paper.

Conflicts of Interest: The authors declare no conflict of interest.

\section{References}

1. Brocca, L.; Melone, F.; Moramarco, T.; Morbidelli, R. Spatial-temporal variability of soil moisture and its estimation across scales. Water Resour. Res. 2010, 46, 1-14. [CrossRef]

2. Brocca, L.; Tullo, T.; Melone, F.; Moramarco, T.; Morbidelli, R. Catchment scale soil moisture spatial-temporal variability. J. Hydrol. 2012, 422-423, 63-75. [CrossRef]

3. Western, A.W.; Grayson, R.B.; Blöschl, G.; Willgoose, G.R.; McMahon, T.A. Observed spatial organization of soil moisture and its relation to terrain indices. Water Resour. Res. 1999, 35, 797-810. [CrossRef]

4. Mguidiche, A.; Provenzano, G.; Douh, B.; Khila, S.; Rallo, G.; Boujelben, A. Assessing hydrus-2D to simulate soil water content (SWC) and salt accumulation under an SDI system: Application to a potato crop in a semi-arid area of central Tunisia. Irrig. Drain. 2015, 64, 263-274. [CrossRef]

5. Baudena, M.; Andrea, F.D.; Provenzale, A. A model for soil-vegetation-atmosphere interactions in water-limited ecosystems. Water Resour. Res. 2008, 44, 1-9. [CrossRef]

6. Hu, W.; Shao, M.G.; Han, F.P.; Reichardt, K.; Tan, J. Watershed scale temporal stability of soil water content. Geoderma 2010, 158, 181-198. [CrossRef]

7. Cantón, Y.; Solé-Benet, A.; Domingo, F. Temporal and spatial patterns of soil moisture in semiarid badlands of SE Spain. J. Hydrol. 2004, 285, 199-214. [CrossRef]

8. Fu, B.J.; Wang, J.; Chen, L.D.; Qiu, Y. The effects of land use on soil moisture variation in the Danangou catchment of the Loess Plateau, China. Catena 2003, 54, 197-213. [CrossRef]

9. Korres, W.; Reichenau, T.G.; Fiener, P.; Koyama, C.N.; Bogena, H.R.; Cornelissen, T.; Baatz, R.; Herbast, M.; Deikkrüger, B.; Vereecken, H.; et al. Spatio-temporal soil moisture patterns-A meta-analysis using plot to catchment scale data. J. Hydrol. 2015, 520, 326-341. [CrossRef]

10. Wang, S.; Fu, B.J.; Gao, G.Y.; Zhou, J.; Jiao, L.; Liu, J.B. Liking the soil moisture distribution pattern to dynamic processes along slope transects in the Loess Plateau, China. Environ. Monit. Assess. 2015, 187, 777-790. [CrossRef] [PubMed]

11. Yang, L.; Chen, L.D.; Wei, W.; Yu, Y.; Zhang, H.D. Comparsion of deep soil moisture in two re-vegetation watershed in semi-arid regions. J. Hydrol. 2014, 513, 314-321. [CrossRef]

12. Yang, L.; Wei, W.; Chen, L.D.; Chen, W.L.; Wang, J.L. Response of temporal variation of soil moisture to vegetation restoration in semi-arid Loess Plateau, China. Catena 2014, 115, 123-133. [CrossRef]

13. Zucco, G.; Brocca, L.; Moramarco, T.; Morbidelli, R. Influence of land use on soil moisture spatial-temporal variability and moitoring. J. Hydrol. 2014, 516, 193-199. [CrossRef]

14. Ersahin, S.; Brohi, A.R. Spatial variation of soil water content in topsoil and subsoil of a Typic Ustifluvent. Agric. Water Manag. 2006, 83, 79-86. [CrossRef]

15. Famiglietti, J.S.; Rudnicki, J.W.; Rodell, M. Variability in surface moisture content along a hillslope transect, Ratttlesnake Hill, Texas. J. Hydrol. 1998, 210, 259-281. [CrossRef]

16. Gómez-Plaza, A.; Martínez-Mena, M.; Albaladejo, J.; Castillo, V.M. Factors regulating spatial distribution of soil water content in small semiarid catchments. J. Hydrol. 2001, 253, 211-226. [CrossRef] 
17. Hébrard, O.; Voltz, M.; Andrieux, P.; Moussa, R. Spatio-temporal distribution of soil surface moisture in a heterogeneously farmed Mediterranean catchment. J. Hydrol. 2006, 329, 110-121. [CrossRef]

18. Qiu, Y.; Fu, B.J.; Wang, J.; Chen, L.D. Soil moisture variation in relation to topography and land use in a hillslope catchment of the Loess Plateau, China. J. Hydrol. 2001, 240, 243-263. [CrossRef]

19. Qiu, Y.; Fu, B.J.; Wang, J.; Chen, L.D. Spatial variability of soil moisture content and its relation to environmental indices in a semi-arid gully catchment of Loess Plateau, China. J. Arid Environ. 2001, 49, 723-750. [CrossRef]

20. Borcard, D.; Gillet, F.; Legendre, P. Numerical Ecology with R; Springer Science \& Business Media: New York, NY, USA, 2011; pp. 154-194.

21. Andrea, B.; Francesc, G.; Jérôme, L.; Eusebi, V.; Francesc, S. Cross-site comparison of variability of DOC and nitrate $c-q$ hysteresis during the autumn-winter period in three Mediterranean headwater streams, a synthetic approach. Biogeochemistry 2006, 77, 327-349. [CrossRef]

22. Baldeck, C.A.; Colgan, M.S.; Féret, J.B.; Levick, S.R.; Martin, R.E.; Asner, G.P. Landscape-scale variation in plant community composition of an African savanna from airborne species mapping. Ecol. Appl. 2014, 24, 84-93. [CrossRef] [PubMed]

23. Madre, F.; Vergnes, A.; Machon, N.; Clergeau, P. Green roofs as habitats for wild plant species in urban landscapes, first insights from a large-scale sampling. Landsc. Urban Plan. 2014, 122, 100-107. [CrossRef]

24. Stibal, M.; Telling, J.; Cook, J.; Mark, K.M.; Anesio, A.M. Environmental controls on microbial abundance and activity on the Greenland ice sheet, a multivariate analysis approach. Microb. Ecol. 2012, 63, 74-84. [CrossRef] [PubMed]

25. Tang, H.; Shi, X.; Wang, X.; Hao, H.H.; Zhang, X.M.; Zhang, L.P. Environmental Controls over Actinobacteria Communities in Ecological Sensitive Yanshan Mountains Zone. Front. Microbiol. 2016, 7, 1-13. [CrossRef] [PubMed]

26. Gu, C.; Laverman, A.M.; Pallud, C.E. Environmental controls on nitrogen and sulfur cycles in surficial aquatic sediments. Front. Microbiol. 2012, 3, 1-11. [CrossRef] [PubMed]

27. Tian, J.; McCormack, L.; Wang, J.Y.; Guo, D.L.; Wang, Q.F.; Zhang, X.X.; Yu, G.R.; Blagodatskaya, E.; Kuzyakov, Y. Linkages between the soil organic matter fractions and the microbial metabolic functional diversity within a broad-leaved Korean pine forest. Eur. J. Soil Biol. 2015, 66, 57-64. [CrossRef]

28. Zhao, Y.; Lu, Q.; Wei, Y.Q.; Cui, H.Y.; Zhang, X.; Wang, X.Q.; Shan, S.; Wei, Z.M. Effect of actinobacteria agent inoculation methods on cellulose degradation during composting based on redundancy analysis. Bioresour. Technol. 2016, 219, 196-203. [CrossRef] [PubMed]

29. Šmilauer, P.; Lepš, J. Multivariate Analysis of Ecological Data Using Canoco 5; Cambridge University Press: Cambridge, UK, 2014.

30. Venkatesh, B.; Lakshman, N.; Purandara, B.K.; Reddy, V.B. Analysis of observed soil moisture patterns under different land covers in Western Gahats, India. J. Hydrol. 2011, 397, 281-294. [CrossRef]

31. Rallo, G.; Agnese, C.; Minacapilli, M.; Provenzano, G. Comparison of SWAP and FAO agro-hydrological models to schedule irrigation of wine grapes. J. Irrig. Drain. Eng. 2012, 138, 581-591. [CrossRef]

32. Motisi, A.; Consoli, S.; Papa, R.; Cammalleri, C.; Rossi, F.; Minacapilli, M.; Rallo, G. Eddy covariance and sap flow measurement of energy and mass exchanges of woody crops in a Mediterranean environment. Acta Hortic. 2012, 951, 121-128. [CrossRef]

33. Hawley, M.E.; Jackson, Y.J.; McCuen, R.H. Surface soil moisture variation on small agricultural watersheds. J. Hydrol. 1983, 62, 179-200. [CrossRef]

34. Ma, H.C.; McConchie, J.A. The dry-hot valleys and forestation in southwest China. J. For. Res. 2001, 12, 35-39. [CrossRef]

35. Tang, Y.; Xie, J.; Sun, H. Revisiting sustainable development of dry valleys in Hengduan Mountains Region. J. Mt. Sci. 2004, 1, 38-45. (In Chinese) [CrossRef]

36. Zhang, J.P.; Yang, Z.; Wang, D.J.; Zhang, X.B. Climate change and causes in the Yuanmou dry-hot valley of Yunnan, China. J. Arid Environ. 2002, 51, 153-162. [CrossRef]

37. Wang, K.Q.; Shen, Y.X.; Chen, Q.B.; Wang, Z.H. Soil water environment of artificial vegetation in Jinshajiang dry-hot valley. Chin. J. Appl. Ecol. 2004, 15, 809-813. (In Chinese)

38. Xiong, D.H.; Zhou, H.Y.; Yang, Z.; Zhang, X.B. Slope lithologic property; soil moisture condition and revegetation in dry-hot valley of Jinsha river. Chin. Geogr. Sci. 2005, 15, 186-192. [CrossRef] 
39. Dong, Y.F.; Xiong, D.H.; Su, Z.A.; Li, J.J.; Yang, D.; Shi, L.T.; Liu, G.C. The distribution of and factors influencing the vegetation in a gully in the dry-hot valley of southwest China. Catena 2014, 116, 60-67. [CrossRef]

40. Lin, Y.M.; Cui, P.; Ge, Y.G.; Chen, C.; Wang, D.J.; Wu, C.Z.; Li, J.; Yu, W.; Zhang, G.S.; Lin, H. The succession characteristics of soil erosion during different vegetation succession stages in dry-hot river valley of Jinsha River, upper reaches of Yangtze River. Ecol. Eng. 2014, 62, 13-26. [CrossRef]

41. Su, Z.G.; Xiong, D.H.; Dong, Y.F.; Li, J.J.; Yang, D.; Zhang, J.H.; He, G.X. Simulated headward erosion of bank gullies in the dry-hot valley region of southwest China. Geomorphology 2014, 204, 532-541. [CrossRef]

42. Zhang, R.Z. Dry Valleys in the Hengduan Mountains; Science Press: Beijing, China, 1992. (In Chinese)

43. National Soil Survey Office. Soils in China; China Agriculture Press: Beijing, China, 1998; pp. $274-275$. (In Chinese)

44. Liu, G.S. Soil Physics and Chemistry Analysis and Description of Soil Profiles; China Standard Press: Beijing, China, 1996. (In Chinese)

45. Beven, K.J.; Kirkby, M. A physical based variable contributing area model of basin hydrology. Hydrol. Sci. Bull. 1979, 24, 43-69. [CrossRef]

46. Moore, I.D.; Burch, G.J.; Mackenzie, D.H. Topographic effects on the distribution of surface soil water and the location of ephemeral gullies. Trans. Am. Soc. Agric. Eng. 1988, 31, 1098-1107. [CrossRef]

47. Cressie, N. Spatial prediction and ordinary kriging. Math. Geol. 1988, 20, 405-421. [CrossRef]

48. Huisman, J.A.; Snepvangers, J.J.J.C.; Bouten, W.; Heuvelink, G.B.M. Mapping spatial variation in surface soil water content: Comparison of ground penetrating radar and time domain reflectometry. J. Hdrol. 2002, 269, 194-207. [CrossRef]

49. Bi, H.X.; Li, X.Y.; Liu, X.; Guo, M.X.; Li, J. A case study of spatial heterogeneity of soil moisture in the Loess Plateau, western China: A geostatistical approach. Intern. J. Sediments Res. 2009, 1, 63-73. [CrossRef]

50. Huang, Y.; Wang, Y.D.; Zhao, Y.; Xu, X.W.; Zhang, J.G.; Li, C.J. Spatiotemporal distribution of soil moisture and salinity in the Taklimakan desert highway shelterbelt. Water 2015, 7, 4343-4361. [CrossRef]

51. Zou, W.X.; Han, X.Z.; Wang, S.Y.; Li, L.H.; Wang, F.J. A study on dynamics of soil moisture of soil profile in black soil. Bull. Soil Water Conserv. 2009, 3, 130-134. (In Chinese)

52. Choi, M.; Jacobs, J.M. Soil moisture variability of root zone profiles within SME02 remote sensing footprints. Adv. Water Resour. 2007, 30, 883-896. [CrossRef]

53. Penna, D.; Borga, M.; Norbiato, D.; Fontana, G.D. Hillslope scale soil moisture variability in a steep alpine terrain. J. Hydrol. 2009, 364, 311-327. [CrossRef]

54. Grayson, R.B.; Western, A.W.; Chiew, F.H.S. Preferred states in spatial soil moisture patterns, local and nonlocal controls. Water Resour. Res. 1997, 33, 2897-2908. [CrossRef]

55. Jin, Z.Z. A phytosociological stuy on the semi-savanna vegetation in the dry-hot valleys of Yuanjiang River, Yunnan. Guihaia 1999, 19, 289-302. (In Chinese)

56. Tanner, C.B.; Jury, W.A. Estimating evaporation and transpiration from a row crop during incomplete cover. Agron. J. 1976, 68, 239-243. [CrossRef]

57. Bagley, J.E.; Desai, A.R.; Dirmeyer, P.A.; Foley, J.A. Effects of land cover change on moisture availability and potential crop yield in the world's breadbaskets. Environ. Res. Lett. 2012, 7, 014009. [CrossRef]

58. Cao, X.; Wu, P.; Zhao, X.; Wang, J.; Shi, Y. Effects of land use on soil moisture variations in a semi-arid catchment, implications for land and agricultural water management. Land Degrad. Dev. 2014, 25, 163-172.

59. Baroni, G.; Ortuani, B.; Facchi, A.; Gandolfi, C. The role of vegetation and soil properties on the spatio-temporal variability of the surface soil moisture in a maize-cropped field. J. Hydrol. 2013, 489, 148-159. [CrossRef]

60. Teuling, A.J.; Uijlenhoet, R.; Hupet, F.; van Loonm, E.; Troch, P.A. Estimating spatial mean root-zone soil mositure from point-scale observations. Hydrol. Earth Syst. Sci. 2006, 10, 755-767. [CrossRef]

61. Li, H.D.; Shen, W.S.; Zou, C.X.; Jiang, J.; Fu, L.D.; She, G.H. Spatio-temporal variability of soil moisture and its effect on vegetation in a desertified aeolian riparian ecotone on the Tibetan Plateau, China. J. Hydrol. 2013, 479, 215-225. [CrossRef]

62. Cerdà, A. The influence of geomorphological position and vegetation cover on the erosional and hydrological processes on a Mediterranean hillslope. Hydrol. Process. 1998, 12, 661-671. [CrossRef]

63. Chanasyk, D.S.; Mapfumo, E.; Willms, W. Quantification and simulation of surface runoff from fescue grassland watersheds. Agric. Water Manag. 2003, 59, 137-153. [CrossRef] 
64. Yao, X.L.; Fu, B.J.; Lü, Y.H.; Chang, R.Y.; Wang, S.; Wang, Y.F.; Su, C.H. The multi-scale spatial variance of soil moisture in the semi-arid Loess Plateau of China. J. Soils Sediment 2012, 12, 694-703. [CrossRef]

65. Brutsaert, W. Evaporation into the Atmosphere, Theory; History and Application; Springer Science \& Business Media: New York, NY, USA, 2013.

66. Singh, J.S.; Milchunas, D.G.; Lauenroth, W.K. Soil water dynamics and vegetation patterns in a semiarid grassland. Plant Ecol. 1998, 134, 77-89. [CrossRef]

67. Ivanov, V.Y.; Fatichi, S.; Jenerette, G.D.; Espeleta, J.F.; Tronch, P.A.; Huxman, T.E. Hysteresis of soil moisture spatial heterogeneity and the "homogenizing" effect of vegetation. Water Resour. Res. 2010, 46, W09521. [CrossRef]

68. Coppens, F.; Gamier, P.; DeGryze, S.; Merckx, R.; Recous, S. Soil moisture, carbon and nitrogen dynamics following incorporation and surface application of labeled crop residues in soil columns. Eur. J. Soil Sci. 2006, 57, 894-905. [CrossRef]

69. Iqbal, A.; Beaugrand, J.; Garnier, P.; Recous, S. Tissue density determines the water storage characteristics of crop residues. Plant Soil 2013, 367, 285-299. [CrossRef]

70. Osman, K.T. Soil Degradation; Conservation and Remediation; Springer: Dordrecht, The Netherlands; Heidelberg, Germany; New York, NY, USA; London, UK, 2014.

71. De Vita, P.; Di Paolo, E.; Fecondo, G.; Di Fonzo, N.; Pisante, M. No-tillage and conventional tillage effects on durum wheat yield; grain quality and soil moisture content in southern Italy. Soil Till. Res. 2007, 92, 69-78. [CrossRef]

72. Takagi, K.; Lin, H.S. Changing controls of soil moisture spatial organization in the Shale Hills Catchment. Geoderma 2012, 173-174, 289-302. [CrossRef]

73. Lal, R. Soil erosion impact on agronomic productivity and environment quality. Crit. Rev. Plant Sci. 1998, 17, 319-464. [CrossRef]

(c) 2017 by the authors; licensee MDPI, Basel, Switzerland. This article is an open access article distributed under the terms and conditions of the Creative Commons Attribution (CC BY) license (http:/ / creativecommons.org/licenses/by/4.0/). 